\title{
Effect of Household Factors on Repayment Ability among Islamic Microfinance Borrowers in Bangladesh
}

\author{
Farzana Sharmin ${ }^{1} \&$ Ridzwan Bakar ${ }^{2}$ \\ ${ }^{1}$ PhD Student, Faculty of Management, Multimedia University, Malaysia \\ ${ }^{2}$ Professional Lecturer, Faculty of Management, Multimedia University, Malaysia \\ Correspondence: Farzana Sharmin, Faculty of Management, Multimedia University, Malaysia. \\ E-mail:kakonbau@gmail.com
}

Received: May 10, 2018

doi:10.5539/ijbm.v13n8p40

\author{
Accepted: June 8, 2018 \\ Online Published: June 30, 2018 \\ URL: https://doi.org/10.5539/ijbm.v13n8p40
}

\begin{abstract}
The paper aims to discuss the effect of household factors on repayment ability among borrowers of Islamic microfinance in Bangladesh. Cross-sectional survey was used on borrowers who have been involved for more than two years in rural development scheme. Data was collected from 507 households through a close-ended questionnaire. The survey found that household income increased significantly after access to the Islamic microfinance program. The structural equation model analysis shows that household income has a significant positive effect on repayment ability. Household savings and consumption were also found to have a significant positive relationship with household income. Household savings also has a significant positive relationship with repayment ability when it is negative with the household consumption. Unlike conventional studies, this study found that borrowers involved in farm activities have a better repayment ability. The emerging result contributes to the research regarding repayment problems and the findings demonstrate that the adoption of Islamic microfinance could be a better solution. It is also anticipated that the empirical result will contribute to the furtherance of literature on Islamic microfinance.
\end{abstract}

Keywords: Islamic microfinance, income, consumption, savings, repayment

\section{Introduction}

Though conventional microfinance is dominant in Muslim majority countries, some Muslims like to stay away from interest-based conventional microfinancing (Karim et al., 2008) as religious issues do matter in microfinance (Ashta \& Hannam, 2014). With the potential to solve religious restrictions, Islamic microfinance has the advantage of reducing fungibility of borrowed funds and increasing the willingness to repay the loan through its interest-free asset based financing mode (El-Komi \& Croson, 2012). Islamic microfinance is a Shari'ah (Islamic laws) compliant method of providing microfinance which increases the productivity of the poor, empowers them, and assists in socio- economic development. More specifically, Islamic microfinance could be defined as a collection of savings and disbursement of small loans based on Islamic principles (Dusuki, 2008). Islamic microfinance has experienced a very short journey and its literature lacks sufficient empirical evidence (Noipom, 2014). The limited empirical research in Islamic microfinance motivates this study.

Islamic microfinance has shifted the focus from 'women empowerment' to 'family (household) empowerment' (Obaidullah, 2008). Hence, the objective of this study is to investigate the effect of household income, savings and consumption on the repayment ability. This study focuses on the repayment ability as it is directly related to the borrowers' welfare and the financial sustainability of microfinance institutions (MFIs). Islamic microfinance borrowers have been found to spend more time on income generating purposes (Ahmed, 2002) and the higher returns from micro investment encourages the borrowers to save more (Rahman, 2010; Chapra, 2008) and also enables them to spend more for consumption (Rahman \& Ahmed, 2010). Changes in income, savings and consumption are a result of the collective activities and resources added to the households due to access from the microfinance program (Alia et al., 2017; Al Mamun, 2011; Chen \& Dunn, 1996). Return on investment or income is one of the critical factors that affect their repayment ability. Low return or income could easily cause borrowers to default and create a bad cycle of poverty (Osmani, 2016). Spending too much for consumption purposes could make the situation worse. It is assumed that savings act as a risk absorber during low income period (Ahsan \& Barua, 2010; Islam, 2009) by smoothing consumption and repayment of the loan. Besides 
higher return on investment, the moral teachings of Islam regarding finance may have a potential impact on the borrower's repayment ability (Nawai \& Shariff, 2012). Moreover, debt is considered the last solution to meeting a crisis as per Islamic Shari'ah laws and the repayment of debt on time or keeping the oath is emphasized (Obaidullah, 2008).

The findings of this study are expected to contribute to the literature of Islamic microfinance which lacks empirical studies. Since empirical evidence on issues related to Islamic microfinance is limited so far, this study uses empirical evidence from conventional microfinance which supports this study as the RDS is designed after the Grameen model except for the operational procedure which is Shari'ah based. Rural Development Scheme (RDS) from Bangladesh is selected as the sample Islamic microfinance program which provides commercial loans on the bai mujjal mode by using the group lending methodology. RDS is one of the largest Islamic microfinance programs in the world and is able to maintain an impressive repayment rate $(99.99 \%)$ with a negligible write-off ratio. Islamic microfinance in Bangladesh mainly started its journey in 1995 in a large scale with the RDS of Islami Bank Bangladesh Ltd. (IBBL). IBBL also started a program named MEIS to support micro-entrepreneurs who are in need of a large amount of loan. According to IBBL, RDS has more than one million clients whereas MEIS has 67,000 clients. Besides IBBL, other banks such as the Al Arafah Islami Bank also provides Islamic MF services to the poor and some conventional MFIs also provide Islamic microfinance services e.g., TMSS in considering their client's demands, provides Islamic microfinance and has around 70,000 client outreach for Islamic microfinance alone. Several international Islamic microfinance providers, e.g., Muslim Aid and Islamic Relief, are also active in Bangladesh and have a significant number of client outreach (more than 200,000 in total).

The statistical analysis of this study found that borrowers' household income increased significantly after accessing RDS program. Household income found to have significant positive effect on repayment ability, household savings and household consumption. However, household savings and consumption both have significant effect on repayment ability but the effect is positive for savings and negative for consumption. During survey, borrowers shared positive opinions about the RDS and the Islamic micro financing system. The next section will describe the literature review followed by a section covering the research methodology used in this study. The statistical analysis results and a discussion of the results are presented in the next section. The last section concludes this study.

\section{Literature Review}

The current financial system is interest-based where interest rate is charged to borrowers, making them repay capital along with additional interest rates. This could create inequality and default in repayment. Arsyad (2006) finds that high interest rates can reduce the willingness to repay loans. Islamic microfinance is an interest-free asset-based financing which could possibly influence the repayment ability. Islamic microfinance provides interest free start-up fund that is very much needed by microenterprises. It overcomes the problem of exorbitant interest rates attached to conventional microfinance. Its asset-based financing has the capability of preventing diversion of funds for consumption purposes. Access to Islamic microfinance assists economically-poor borrowers to start income generating activities. Most of the Islamic microfinance borrowers are poor thus access to Islamic microfinance increases their utility and removes barriers to income generation.

Repayment is essential for both borrowers and MFIs as regular repayment protects borrowers from being thrown into a poverty cycle and it ensures the sustainability of the MFIs. Borrowers could default due to sudden losses or moral hazards, also known as voluntary and involuntary defaults, respectively. Osmani (2016) concludes from his study in Bangladesh that low return on investment is one of the major causes of being a defaulter and Oke et al. (2007) advocate that it is the business profit that enables the borrowers to repay regularly. Misuse of funds creates problems in the return on investment or business profit and encourages the borrowers to borrow from multiple sources to repay the loan (Haque \& Yamao, 2008). Islamic microfinance has the ability to stop fund deviation and multiple borrowing as it is an asset-based, i.e. non-monetary based, financing system (El-Komi \& Croson, 2012; Ahmed, 2002). Skill building training or several non-financial training is one of the procedures adopted by microfinance programs to reduce involuntary default. Osmani (2016) advocates that one of the greatest successes of microfinance is that it is able to train its borrowers to repay the loan. Godquin (2004) suggested that training on business management and financial literacy could reduce repayment default. Nawai and Shariff (2012) and Obaidullah (2008) argue that religious teaching is also important from the Islamic point of view as in Islam, debt is the last solution for believers and their soul would be hanged if they do not repay their debt. Monitoring is used to create peer pressure on borrowers and poor monitoring indicates higher chances of being defaulters (Deininger \& Liu, 2009). According to Agbeko et al. (2017), monitoring is a way to reduce repayment default. 
The studies available in Islamic microfinance show that after having access to Islamic microfinance programs, household incomes increase significantly (Noipom, 2014; Shirazi, 2012; Rahman \& Ahmed, 2010). According to Chen and Dunn (1996), access to credit adds resources to the households and this increases household activities that results in increased household income as well as household assets, consumption, and investment. They also argue that a part of the generated income flows out of household income to repay the loan. The model of Chen and Dunn (1996) known as the household economic portfolio model (HEPM) was later modified by several researchers including Alia et al. (2017) and Al Mamun (2011). The modified model considers the informal services (training or meeting) provided by the MFIs and the benefit that the households draw from the social network. Al Mamun (2011) in his modified model adds that aside from credit, it is the informal services that bring changes to the households which ultimately increases household asset and income and reduces the repayment problem. In addition to all these modifications, Alia et al. (2017) argue that for low income households, time and credit complement each other. That is, borrowers of MFIs benefit from credit as well as their membership duration and/or time spent in income generating activities. Consequently, there are many factors in the household responsible for increased income, savings (liquid asset), and consumption thus this study focuses on the household factors i.e., income, consumption, and savings to understand the effect of Islamic microfinance on repayment ability.

Income is an economic indicator of a household's welfare. However, the income of the poor household changes drastically as they face substantial idiosyncratic and common risks (Dercon, 2002). Hence, to measure household income, the focus is on the expenditure of the household (Moratti \& Natali, 2012; Rahman et al., 2009). Household expenditure reflects income properly as it provides a basis to analyze the change in purchasing power of the household and it is found that after accessing a microfinance program, the borrower's ability to spend on various household needs increases significantly (Adjei et al., 2009). Households could spend their income for several purposes including food, housing, treatment or heath purposes and education. Khandker (2005) finds that borrowers' expenditure for food purposes increased significantly compared to non-borrowers. Since borrowers spend a major part of their income for food (Rahman \& Ahmed, 2010), it is found by Agbola et al. (2017) that per capita food expenditure differs significantly between borrowers and non-borrowers. The health of the members of borrower's household is found to have improved as the borrowers spend their income for treatment or health purposes (Agbola et al., 2017; Samer et al., 2015). Borrowers' housing condition is also found to have improved due to their increased ability to spend (Mazumder \& Lu, 2015) and established borrowers are found to spend more for education purposes (Onyina \& Turnell, 2013).

On the other hand, Nawai and Shariff (2012); Brehenu and Fufa (2008) assume that the causes responsible for lower household income or lower return on investment are also responsible for the repayment problem. Lower profit or income of poor households may make borrowers unable to have extra money to repay the loan after expenses for consumption or other basic purposes. Hence, household income and repayment ability has a significant positive relationship.

Hypothesis 1: Household income has a significant positive effect on repayment ability.

Household consumption and savings are the most important economic factors related to household income and repayment ability. Households mainly spend their permanent income for smoothing consumption and extra income for savings. In low income households, it is quite difficult to differentiate permanent and temporary income. The permanent income hypothesis (PIH) of Friedman (1957) posits that savings and consumption are products of income. Individuals are interested in savings when they assume that their future income could be interrupted and also for their unemployed period. Chowa et al. (2012) reveal that income is a significant predictor of savings and savings of households increase with increased income. Ashraf et al. (2010) and Goldberg (2005) find that after having access to microfinance programs, borrowers' household savings increased significantly. However, borrowers always have a purpose in their mind for which they are saving including saving for housing, treatment, education, reinvestment, celebration, etc. (Ashraf et al., 2010).

Hypothesis 2a: Household income has a significant positive impact on household savings.

A part of income that is not spent for any purpose or that deferred consumption is defined as savings. Microfinance borrowers could have both commitment and voluntary savings. In their study on Bangladesh, Raihan et al. (2017) find that savings are mandatory since microfinance borrowers are unable to repay loans during the destructive flood of 1988. Thus, savings are designed to protect borrowers from being indebted due to default in repayment. The microfinance borrowers found to prefer use savings for repayment (Ahsan \& Barua, 2010) and they demobilize savings easily to repay the loan (Islam, 2009). Al Mamun et al. (2011) also found that household savings of microfinance borrowers have a significant negative relationship with repayment problem. 
Household savings could be a mediator between household income and repayment ability as it increased with income and used to repay loan. As such, this paper has developed two hypotheses based on the above argument.

Hypothesis 2b: Household savings have a positive relationship with repayment ability.

Hypothesis 2c: Household savings mediate the relationship between income and repayment ability.

According to the utility theory, access to credit and availability of savings smoothens households' consumption. Consumption is the first priority of poor household and increased after access to microfinance program (Mahjabeen, 2008) as large part of increased income spent for household consumption (Rahman \& Ahmed, 2010). For measuring household consumption this study focuses on nutrition consumption and meal quality. Research conducted by Doocy et al. (2005) shows that participation in microfinance programs significantly increases the meal quality and the consumption of meat and fish among the borrowers. Friedman (1957) hypothesized that consumption is product of income and consumption is determined by present and expected future income as well. Nawai and Shariff (2012) found that 11\% Malaysian borrowers default in repayment due to use their borrowed loan for consumption purposes. Consumption gratification could make the poor households unable to have any extra money for other purposes (Chowa et al., 2012). In a study on Bangladesh Haque and Yamao (2008) also found that large expense on household consumption make the borrowers defaulter.

Hypothesis 3a: Household income has a significant positive impact on household consumption.

Hypothesis 3b: Household consumption has a negative relationship with repayment ability.

Hypothesis 3c: Household consumption mediates the relationship between income and repayment ability.

One of the significant contributions of microfinance services is to involve borrowers and their households in different income generating activities to secure long term income (Al Mamun, 2011). Hence, microfinance provides loans for several purposes ranging from off-farm activities to farm activities to encourage borrowers to be involved in a wide range of economic activities. Brehenu and Fufa (2008) assume that income generating activities or usage of loan for several income generating activities have an effect on repayment ability as well. The microfinance borrowers prefer to engage in off-farm activities as it provide quick return or profit and less prone to any natural disaster or uncertain losses. Moreover, borrowers involve in off-farm activities could easily demobilize their entrepreneurial asset to repay the loan if they face severe crisis. From a study, Roslan and Abd Karim (2009) advocate that there are fewer defaulters among borrowers involved in non-agricultural or off-farm activities. Thus, this leads to the final hypothesis of this study.

Hypothesis 4: The purposes of loan for income generation have a moderating effect on the relationship between income and repayment ability.

\section{Research Methodology}

This paper is an exploratory study of the repayment ability of Islamic microfinance borrowers. For data collection, RDS from Bangladesh is selected as the focus. RDS is designed after the "Grameen Model" but operates based on Islamic financing principles. Unlike other emerging Islamic microfinance programs, the RDS has adopted Islamic financing instruments including bai muajjal, ijarah, and qard hasan. Hence, the RDS provides real asset-based financing which reduces repayment hazards. Data was collected through a cross sectional survey from five different administrative areas of Bangladesh. Borrowers of more than two years were selected for the interview and a total of 507 respondents were interviewed. Borrowers were interviewed during their group meetings, and were asked several questions and their opinion towards the RDS. According to Gaile and Foster (1996), a sample of 500 could control any type of bias for microfinance borrowers. To achieve a good sample size, data was collected from 507 households through a well-structured close-ended questionnaire. Data was collected during group meetings to verify the borrowers' responses and reduce the chances of over or under-estimation. Responses on economic factors were recorded in a five-point Likert scale and borrowers replied on their level of agreement from decreased greatly (1) to increased greatly (5) with 'remain the same' assigned a value of (3). Out of the 507 responses, 497 were found suitable for data analysis after removing those with missing and unreliable data.

For data analysis, this study developed a simple structural equation model (SEM) on the basis of theory and empirical evidence from literature. Household income is the independent variable and repayment ability as the dependent variable whereas household consumption and household savings are the mediating variables. The main focus of microfinance is to reduce diversity and inequality in income (Kandker, 2005) and income is an overall economic indicator which is able to explain welfare on its own (Al Mamun et al., 2011). Hence, this study relates repayment ability with income, and the purpose of loan for income generation is used as the moderating variable. The variables of the study's SEM are reflective in nature and use a set of measuring items 
to quantify the variables. The items would be validated in the measurement model during the analysis of the model. This study uses the SPSS-AMOS (version 22) for data analysis.

\section{Results and Discussion}

This study uses both the demographic information and SEM analysis to analyze the factors that affect the repayment ability of Islamic microfinance borrowers.

\subsection{Descriptive Statistics}

Table 1 provides a breakdown of the demographic profile of the respondents in this study. Unlike the conventional microfinance, RDS does not focus on women borrowers only. This is evident here as out of 497 borrowers, 422 are female borrowers while 75 are male borrowers which are $84.91 \%$ and $15.1 \%$ of the total sample size, respectively. This is complementary to Islamic microfinancing principles which are focused on household development rather than women empowerment alone (Obaidullah, 2008).

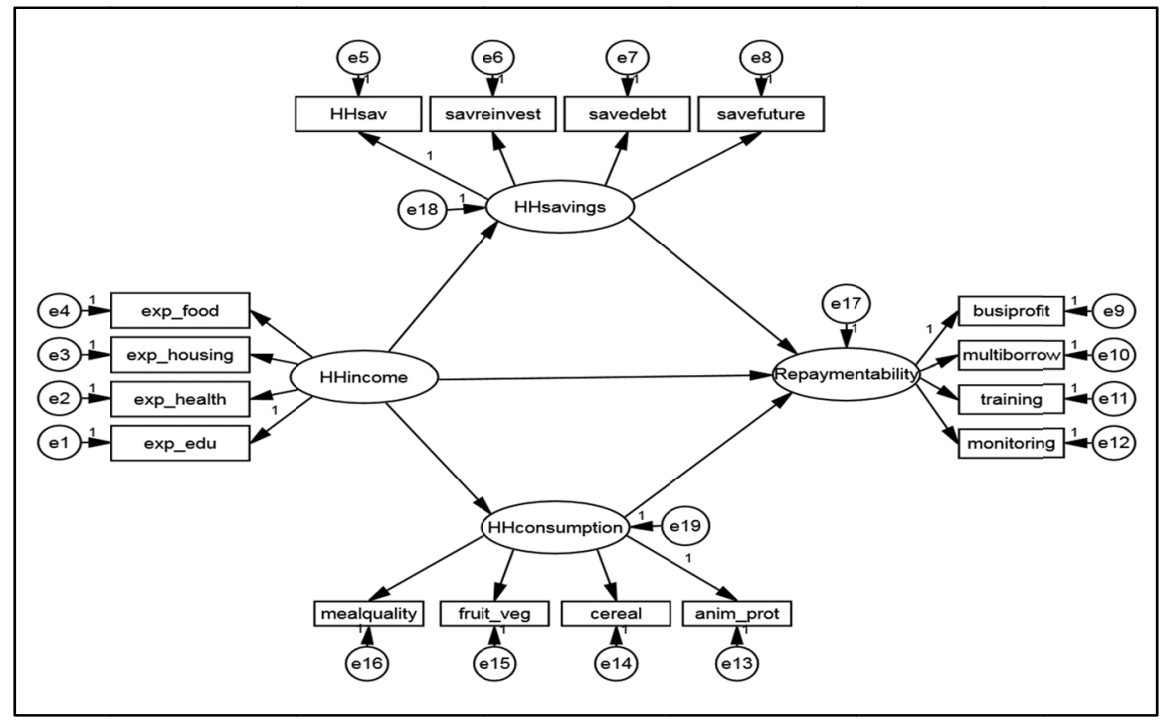

Figure 1. Household factors those affect repayment ability

This study finds that among the sample population, 495 borrowers are married which is $99.6 \%$ of the total sample size. Among the sample population, one borrower is divorced and one borrower is a widow making up $0.2 \%$ of the sample population. It is also found that the age group of 31-35 years old are the largest group of clients with 294 borrowers at $59.12 \%$ of the total population. Meanwhile, the age group of 26-30 years old come second with 90 borrowers at $18.12 \%$ of the total sample and the 36-40 years age group third with 70 borrowers at $14.08 \%$ of the total population. From the sample population, it is found that the minimum age of the borrowers is 22 while the maximum is 44 with a mean of 31.97 years. One of the five objectives of the RDS is to create employment opportunities for poor youth and the age range reflects their objectives. Though primary education is obligatory in Bangladesh for a long time now and the government is trying to improve the literacy rate for the country, this study shows 52 borrowers, i.e. 10.46\%, did not receive any institutional education. These borrowers did not go to school but are able to sign their name and have some knowledge on numerical literacy. Access to the RDS program increased their ability to manage the business and keep records of transactions. Out of the 497 borrowers, 272 borrowers have primary education and 169 have secondary education which is $54.73 \%$ and $34.0 \%$ of the sample population, respectively. Moreover, this survey found only $4(0.8 \%)$ borrowers with a college education.

RDS also provides a wide variety of loans for borrowers including foe crop production, livestock production, manufacturing and processing, trading, shopkeeping, plantation, paddling, service, among others. To make the data analysis easier, this study classifies crop and livestock under agricultural activities and micro business represents trading and shopkeeping. The collected data reveals that $39.64 \%$ of the borrowers use their loan for agricultural activities, $50.5 \%$ in micro business, $4.02 \%$ for manufacturing and processing, and the rest of the borrowers $(5.84 \%)$ use the loan in the service sector. Hence, this study finds that a majority of the borrowers $(50.5 \%)$ use their loan for micro business purposes because they find this to be less risky and quick for profit 
generation. For structural analysis this study classifies the agricultural activities as 'farm activities' and other non-agricultural activities as 'off farm' activities.

Table 1. Demographics of respondents $(n=497)$

\begin{tabular}{lcc}
\hline Item & Frequency & Percentage \\
\hline Gender & & \\
Male & 75 & 15.10 \\
Female & 422 & 84.91 \\
Age & & \\
$21-25$ years & 38 & 7.65 \\
26-30 years & 90 & 18.12 \\
31-35 years & 294 & 59.12 \\
36-40 years & 70 & 14.08 \\
$41-45$ years & 5 & 1.01 \\
Education level & & \\
No education & 52 & 10.46 \\
Primary education & 272 & 54.73 \\
High school & 169 & 34.0 \\
College & 4 & 0.8 \\
Marital Status & & \\
Married & 495 & 99.6 \\
Divorced & 1 & 0.2 \\
Widow & 1 & 0.2 \\
Usage of loan & & \\
Agricultural activities (crop and livestock production) & 197 & 39.64 \\
Micro business (trading and shopkeeping) & 251 & 50.5 \\
Manufacturing and processing & 20 & 4.02 \\
Service & 29 & 5.84 \\
\hline
\end{tabular}

Borrowers were also asked about their income and they were provided a range of options to select from. A suitable range was used in order to make the interview easy and the borrowers were also free to share personal information as the actual amount of income is a sensitive issue to discuss (Ahsan \& Barua, 2010). Table 2 presents a range of household incomes before and after participation in the RDS program. Here, the 'income before' dictates the household's monthly average income at the moment of participation in RDS and 'income after' refers to income at the time of data collection or income at present. It is notable that for the present income, borrowers were asked their monthly average income over the last twelve months and not the income of the present month as income of poor households is very sensitive and changes drastically.

Table 2 shows that every household has a higher income after participation. From the income level, it is also observed that $16.1 \%$ borrowers were under the poverty line and they were able to get out of this after participation. According to the borrowers' opinion, several reasons including the asset based Islamic loan and non-financial assistance are responsible for the increased income of households. Noipom (2014), Shirazi (2012), Rahman and Ahmed (2010) also found that Islamic microfinance intervention increased household income. A non-parametric test (Wilcoxon Signed Ranks Test) was conducted to analyze the significance of the changes in income before and after participation in the Islamic microfinance schemes. It is found that the $p$-value is significant at the 0.01 level. Thus, it is also statistically proven that household income differs significantly before and after participation in the RDS program. 
Table 2. Range of monthly household income before and after participation

\begin{tabular}{|c|c|c|c|c|}
\hline \multirow[t]{2}{*}{ Income range } & \multicolumn{2}{|c|}{ Income before } & \multicolumn{2}{|c|}{ Income after } \\
\hline & Count $(\mathrm{N})$ & $\%$ & Count $(\mathrm{N})$ & $\%$ \\
\hline Below 5000TK & 80 & 16.1 & - & - \\
\hline 5001-7000TK & 296 & 59.56 & 168 & 33.8 \\
\hline 7001-9000TK & 117 & 23.54 & 198 & 39.84 \\
\hline 9001-11000TK & 4 & 0.8 & 105 & 21.13 \\
\hline $11000-13000 \mathrm{TK}$ & - & - & 23 & 4.63 \\
\hline More than $13000 \mathrm{TK}$ & - & - & 3 & 0.60 \\
\hline
\end{tabular}

Finally, in the demographic section, borrowers were asked for their opinion of Islamic principles of RDS and its rebate (incentive) system. Among the sample borrowers, $96.58 \%$ of borrowers replied that they have no problem with the Islamic principles, teaching or financing system of RDS. All borrowers agree with the statement that they found religious teachings to be useful to them. However, $3.42 \%$ of borrowers replied that initially they had some difficulties in understanding the financing system. Rebate or incentive on regular repayment encourages borrowers to repay on time and $98.59 \%$ of borrowers agreed that the incentive motivated them. The rest of the borrowers $(1.41 \%)$ replied that they would repay the loan even if RDS does not have incentive facilities.

\subsection{Output of SEM}

The model uses unobserved variables measured by using several question items. In SEM, the CFA must be conducted for the variables with the measuring items, validated in the measurement model, and then the structural analysis is run to find out the statistical result of the causal relationship.

In this study, the questionnaire items or measuring items were confirmed by CFA and the measurement model is valid. Table 3 presents the validity and reliability indicators of the measurement model. It is notable that the validity of the measurement model not only validates the measurement items but also the theory or evidence based on which the model is designed. From the CFA, it is found that all the factors have a loading of more than 0.6; AVE (Average Variance Extracted) was found to be more than 0.5, and the CR (Convergent Reliability) was more than 0.7. Hence the measurement model is valid according to Bryne, 2010 and Hair et al., 2010. The correlation value between two constructs was found to be less than 0.90 which confirms the discriminant validity of the measurement model (Hair et al., 2010).

Table 3. Reliability and validity of measurement model

\begin{tabular}{|c|c|c|c|c|}
\hline Constructs & Measuring items & Factor loadings & AVE & $\mathrm{CR}$ \\
\hline \multirow[t]{4}{*}{ HHincome } & exp_food & 0.899 & 0.524 & 0.813 \\
\hline & exp_housing & 0.982 & & \\
\hline & exp_health & 0.685 & & \\
\hline & exp_edu & 0.619 & & \\
\hline \multirow[t]{4}{*}{ HHsavings } & HHsav & 0.824 & 0.516 & 0.809 \\
\hline & Savdebt & 0.675 & & \\
\hline & Savereinvest & 0.732 & & \\
\hline & savefuture & 0.680 & & \\
\hline \multirow[t]{4}{*}{ HHconsumption } & mealquality & 0.895 & 0.545 & 0.814 \\
\hline & Cereal & 0.627 & & \\
\hline & anim_prot & 0.822 & & \\
\hline & fruit_veg & 0.618 & & \\
\hline \multirow[t]{4}{*}{ Repaymentability } & busiprofit & 0.967 & 0.511 & 0.954 \\
\hline & multiborrow & 0.856 & & \\
\hline & Training & 0.910 & & \\
\hline & monitoring & 0.862 & & \\
\hline
\end{tabular}

The next step is to go for the structural analysis to analyze the causal relationship. The first step of the structural analysis is to measure the model's fit. Table 4 presents the model fit of the structural model and it shows that the 
model is fit enough for further analysis.

Table 4. Fitness of structural model

\begin{tabular}{lll}
\hline Indicators & Standard value* & Model Output \\
\hline CMIN/DF & $\leq 3$ (acceptable lower than 5$)$ & 1.818 \\
RMSEA & $\leq 0.80$ & 0.040 \\
CFI & $\geq 0.90($ better closer to 1$)$ & 0.985 \\
GFI & $\geq 0.90($ better closer to 1$)$ & 0.959 \\
AGFI & $\geq 0.90($ better closer to 1$)$ & 0.942 \\
RFI & $\geq 0.90($ better closer to 1$)$ & 0.959 \\
IFI & $\geq 0.90$ (better closer to 1$)$ & 0.985 \\
TLI & $\geq 0.90$ (better closer to 1) & 0.981 \\
Hoelter's critical N & $>200$ & 374 \\
\hline
\end{tabular}

*Source: Bryne (2010) and Hair et al (2010).

In addition to the good model fit, the assumption for normality is also fulfilled for the data as the skewness of the dataset is between +2 and -2 (Tabachnick \& Fidell, 2007) and the kurtosis is between +7 to -7 (Bryne, 2010). Table 5 presents the level of significance of the hypothesized causal relationship between variables in the model. The table shows that income has a significant positive effect on household consumption, household savings, and repayment ability. The table also shows that household savings and household consumption has a significant effect on repayment ability. As expected, the result shows that household consumption has a negative relationship with repayment ability.

Table 5. Significance of causal paths

\begin{tabular}{|c|c|c|c|}
\hline Causal Paths & Standardized Regression & Unstandardized Regression & $P$ value \\
\hline & Weight & Weight & \\
\hline $\mathrm{HH}$ income $\longrightarrow$ Repaymentability & 0.205 & 0.299 & 0.034 \\
\hline $\mathrm{HH}$ income $\longrightarrow \mathrm{HH}$ consumption & 0.201 & 0.301 & 0.000 \\
\hline $\mathrm{HH}$ income $\longrightarrow$ HH savings & 0.141 & 0.181 & 0.000 \\
\hline $\mathrm{HH}$ consumption $\longrightarrow$ Repaymentability & -0.155 & -0.222 & 0.009 \\
\hline $\mathrm{HH}$ savings $\longrightarrow$ Repaymentability & 0.167 & 0.259 & 0.008 \\
\hline
\end{tabular}

Table 5 shows that household consumption and household savings have a significant relationship with both predictor (income) and outcome (repayment ability) variables and the standardized value decreases after the introduction of the mediator. Thus, household consumption and savings mediate the relationship between the variables HHincome and Repaymentability (Fraizer et al., 2004). This research also utilized the usage of loan or income generating purpose as the moderating variable for the relationship between income and repayment ability. The differed CMIN value between constrained and unconstrained measurement model is higher than the chisq value at the differed degrees of freedom. Thus, the usage of loan has a moderating effect on the causal paths. Table 6 presents the results of the moderating effect of usage of loan and shows that farm activities have a better effect on repayment ability. 
Table 6. Moderating effect of usage of loan

\begin{tabular}{lll}
\hline Causal Paths & Farm activities & Off farm activities \\
\hline HHincome & $0.201^{* * *}$ & 0.159 \\
HHincome & $0.341^{* * *}$ & 0.103 \\
HHincome HHconsumption & $0.155^{* * *}$ & 0.107 \\
HHconsumption & $0.246^{* * *}$ & 0.055 \\
HHsavings & $0.219^{* * *}$ & 0.062 \\
\hline
\end{tabular}

\subsection{Discussion}

A simple structural equation model is used to identify the factors related to the repayment ability of borrowers. The causal output from the structural model provides empirical evidence that the household income has a direct significant effect on the repayment ability. This finding is similar to Al Mamun et al. (2011). The increased income results in increased borrowers' savings capacity and household consumption. A part of the income also came out of the household economic activities to repay the loan. The positive relationship between household income and repayment ability supports the assumption of Brehenu and Fufa (2008) and Nawai and Shariff (2012) that income affects the repayment ability.

The analysis also finds that household savings and consumption increases with income and these findings are in line with the theory of the savings' 'permanent income hypothesis' (Friedman, 1957). Islamic microfinance lacks sufficient empirical evidence to support the result but Chapra (2008) claims that household savings could increase after joining Islamic microfinance. Studies from conventional microfinance show that household savings increase with household income (Ashraf et al., 2010; Goldberg, 2005). Research from conventional microfinance find that consumption is always the first priority of poor households. The empirical result of this study also finds evidence that household consumption increases with household income, confirming the results of Rahman and Ahmed (2010) who find that with the increased income, consumption also increased in households with RDS borrowers.

Savings is the liquid asset of households that provide economic security and act as an insurance for poor households. Savings product was introduced in Bangladesh's microfinance system by the Grameen Bank to reduce the borrowers' repayment difficulties (Raihan et al., 2017). Ahsan and Barua (2010) and Islam (2009) suggest that sometimes savings are demobilized to repay loans and the borrowers of this study agree that they saved a part of their income to pay their personal debt. The structural result shows a positive and significant causal relationship between household savings and repayment ability. The data analysis in this study also finds a significant relationship between household consumption and repayment ability. Household consumption is found to have a negative relationship with repayment ability implying that consumption could increases problems in repayment, consistent with the findings of Nawai and Shariff (2012) and Haque and Yamao (2008). Hence, a negative relationship between consumption and repayment ability is expected. Restricted gratification of consumption and wise expenditure planning may assist the poor households to reduce their repayment hazards. Household savings and consumption are both found to act as a mediator between household income and repayment ability.

Further, this study finds the moderating effect of purpose of loan for income generating activities. It is found that borrowers involved in agricultural or farm activities have better repayment ability which is contrary to the findings of Roslan and Abd Karim (2009). Data on MFIs shows that diversity of loan purposes increased over year. According to CDF Bangladesh (www.cdfbd.org), MFIs have started to provide their loans to finance a wide range of activities and have not limited their scope to trading or small businesses only. Now MFIs encourage their borrowers to engage in several agricultural activities including fishing, crop and fruits production, vegetables production, livestock production, among others.

\section{Conclusion}

The purpose of this study is to find out the factors of the household that affect the repayment ability of Islamic microfinance borrowers. For data analysis, this study selected the RDS from Bangladesh which does not focus on women borrowers only. This study strengthens and deepens the understanding of how some household factors of Islamic microfinance borrowers makes a positive impact on repayment ability. Evaluating the repayment ability is important as it is directly related to the borrowers' welfare and financial sustainability of MFIs. Though conventional microfinance is able to maintain an impressive repayment rate, the dropout rate affects the welfare 
of the borrowers. This study offers findings on the basis of Islamic microfinance that is an interest-free asset-based financing with incentives and religious teaching needed by the poor to increase their repayment ability. Apart from that, borrowers must use their loan properly to generate income or profit which would finally assist them to repay regularly. The findings of this study are found to complement the utility theory and the theory of savings which shows that though these theories are expanded in developed countries with high or middle income households, it is still suitable for poor households in developing countries.

Based on the findings of this study and considering the similarities of findings with other studies, this study suggests the generalization and application of similar Islamic microfinance programs in other developing countries especially where Muslims with low household income are unable to access the formal (conventional) financing system. This study also provides valuable insights to policy makers, academicians, and practitioners, particularly in developing countries, by identifying the factors which could affect the repayment ability.

For the policy maker, this study shows that borrowers need interest free loans with incentives for regular repayment and religious training to assure higher household income, savings, and consumption which would significantly affect the repayment ability. This study also sends a positive message to use loans for a variety of purposes and to expand the investment on the agricultural sector. This investigation also has theoretical implications as the causal relationships and their findings are quite complementary to the utility theory and the theory of savings. Hence, this study significantly contributes to the Islamic microfinance literature.

Further studies are suggested to be carried out by using the total and actual value of the savings, income, and consumption instead of making general statements based on the Likert scale. This article has some limitations since it is only focused on Muslim borrowers, and does not consider non-participants or non-Muslims. Future studies could consider this suggestion as non-participants or non-Muslims may have different opinions and understanding about the Islamic microfinance.

\section{References}

Adjei, J. K., Arun, T., \& Hossain, F. (2009). The Role of Microfinance in Asset-Building and Poverty Reduction: The Case of Sinapi Aba Trust of Ghana. BWPI. The University of Manchester, Brooks World Poverty Institute Working Paper Series.

Agbeko, D., Blok, V., Omta, S. W. F., \& Van Velde, G. (2017). The impact of training and monitoring on loan repayment of microfinance debtors in Ghana. Journal of Behavioral and Experimental Finance, 14, 23-29. https://doi.org/10.1016/j.jbef.2017.03.002

Agbola, F. W., Acupan, A., \& Mahmood, A. (2017). Does microfinance reduce poverty? New evidence from Northeastern Mindanao. The Philippines. Journal of Rural Studies, 50, 159-171. https://doi.org/10.1016/j.jrurstud.2016.11.005

Ahmed, H. (2002). Financing Micro Enterprises: An Analytical Study of Islamic Microfinance Institutions. Journal of Islamic Economic Studies, 9(2).

Ahsan, S. M., \& Barua, S. (2010). Health Risk in Bangladesh: Can Micro insurance Prevent Vulnerability to Poverty. Working papers no 3. A paper outcome of DFID's PROSPER project at the Institute of Microfinance, Bangladesh.

Al Mamun, A. (2011). Impact of Amanah Ikhtiar Malaysia's Schemes on Hardcore poor households in Peninsular Malaysia. Thesis submitted in fulfillment of the requirement for the degree of Doctor of Philosophy (Unpublished Thesis). Faculty of Management, Multimedia University, Malaysia.

Al Mamun, A., Wahab, S. A., Malarvizhi, C. A., \& Mariapun, S. (2011). Examining the Critical Factors Affecting the Repayment of Microcredit Provided by Amanah Ikhtiar Malaysia. International Business Research, 4(2). https://doi.org/10.5539/ibr.v4n2p93

Alia, H., Ashta, A., \& Ratsimalahelo, Z. (2017). A modified household economic portfolio model for assessing impact of microfinance using diaries. Qualitative Market Research: An International Journal, 20(1), 2-27. https://doi.org/10.1108/QMR-06-2016-0054

Arsyad, L. (2006). Assessing Factors Affecting the Repayment Rate of Microfinance Institutions: A Case Study of Village Credit Institutions of Gianyar, Bali. Gadjah Mada International Journal of Business, 2, 247-273. https://doi.org/10.22146/gamaijb.5618

Ashraf, N., Karlan, D., \& Yin, W. (2010). Female Empowerment: Impact of a Commitment Savings Production the Philippines. World Development, 38(3), 333-344. https://doi.org/10.1016/j.worlddev.2009.05.010 
Ashta, A., \& Hannam, M. (2014). Hinduism and Microcredit. Journal of Management Development, 33(8/9), 891-904. https://doi.org/10.1108/JMD-07-2013-0091

Brehanu, A., \& Fufa, B. (2008). Repayment rate of loans from semi-formal financial institutions among small-scale farmers in Ethiopia: Two-limit Tobit analysia. The Journal of Socio-Economics, 37, 2221-2230. https://doi.org/10.1016/j.socec.2008.02.003

Byrne, B. M. (2010). Structural Equation Modeling with AMOS. Basic concepts, application and Programming. (2nd ed.). Routledge, Tailor \& Francis group.

Chapra, M. U. (2008). Ibn Khaldun's theory of development: Does it help explain the low performance of the present-day Muslim world? The Journal of Socio-Economics, 37, 836-863. https://doi.org/10.1016/j.socec.2006.12.051

Chen, M. A., \& Dunn, E. (1996). Household Economic Portfolios. AIMS Project. Washington, D.C.: Management Systems International.

Chowa, G. A. N., Masa, R. D., \& Ansong, D. (2012). Determinants of Saving among Low-Income Individuals in Rural Uganda: Evidence from Assets of Africa. Advances in Applied Sociology, 2(4), 280-291. https://doi.org/10.4236/aasoci.2012.24037

Deininger, K., \& Liu, Y. (2009). Determinants of repayment performance in Indian Micro-credit Groups. Policy research working paper 4885 . The World Bank development research group, Sustainable rural and urban development.

Dercon, S. (2002). Income risk, coping strategies, and safety nets. The World Bank Research Observer, 17(2), 141-166.

Doocy, S., Teffera, S., Norell, D., \& Burnham, G. (2005). Credit program outcomes: Coping capacity and nutritional status in the food insecure context of Ethiopia. Social Science and Medicine, 60(10), 2371-2382. https://doi.org/10.1016/j.socscimed.2004.10.025

Dusuki, A.W. (2008). Banking for the poor: The role of Islamic banking in microfinance initiatives. Humanomics, 24(1), 49-66. https://doi.org/10.1108/08288660810851469

El-Komi, M., \& Croson, R. (2012). Experiments in Islamic Microfinance. Science Direct, 1-101. https://doi.org/10.1016/j.jebo.2012.08.009

Frazier, P. A., Tix, A. P., \& Barron, K. E. (2004). Testing moderator and mediator effects in counseling psychology research. Journal of counseling psychology, 51(1), 115. https://doi.org/10.1037/0022-0167.51.1.115

Friedman, M. (1957). A theory of the consumption function. Princeton, NJ: Princeton University Press.

Gaile, G. L., \& Foster, J. (1996). Review of Methodological Approaches to the Study of the Impact of Microenterprise Credit Programs, Assessing the Impact of Microenterprise Services. Washington, D.C.: Management Systems International.

Godquin, M. (2004). Microfinance Repayment Performance in Bangladesh: How to Improve the Allocation of Loans by MFIs, World Development, 32(11), 1909-1926. https://doi.org/10.1016/j.worlddev.2004.05.011

Goldberg, N. (2005). Measuring the Impact of Microfinance: Taking Stock of What We Know. Grameen Foundation USA publication series.

Hair, J. F., Black, W. C., Babin, B. J., \& Anderson, R. E. (2010). Multivariate Data Analysis (7th ed.). NJ: Prentice Hall.

Haque, M. S., \& Yamao, M. (2008). Can Microcredit Alleviate Rural Poverty? A Case Study of Bangladesh. Proceedings of World Academy of Science, Engineering and Technology, 36.

Islam, N. (2009). Can Microfinance Reduce Economic Insecurity and Poverty? By How Much and How? United Nations, Department of Economics and Social Affairs, DESA Working Paper No. 82ST/ESA/2009/DWP/82 October 2009. http://dx.doi.org/10.18356/a39cdf00-en

Karim, N., Tarazi, M., \& Reille, X. (2008). Islamic microfinance: an emerging market niche. CGAP Focus Note, 49.

Khandker, S. R. (2005). Microfinance and poverty: evidence using panel data from Bangladesh. The World Bank Economic Review, 19(22), 263-286. https://doi.org/10.1093/wber/lhi008 
Mahjabeen, R. (2008). Microfinancing in Bangladesh: Impact on households, consumption and welfare. Journal of Policy modeling, 30(6), 1083-1092. https://doi.org/10.1016/j.jpolmod.2007.12.007

Mazumder, M, S., \& Lu, W. (2015). What Impact Does Microfinance Have on Rural Livelihood? A Comparison of Governmental and Non-Governmental Microfinance Programs in Bangladesh. World Development, 68, 336-354. https://doi.org/10.1016/j.worlddev.2014.12.002

Moratti, M., \& Natali, L. (2012). Measuring Household Welfare: Short versus long consumption modules. Working Paper 2012-04, UNICEF Office of Research, Florence.

Nawai, M., \& Shariff, M, N, M. (2012). Factors affecting repayment performance in microfinance programs in Malaysia. Procedia-Social and Behavioral Sciences, 62,806-811. https://doi.org/10.1016/j.sbspro.2012.09.136

Noipom, T. (2014). Can Islamic Micro-financing improve the Lives of the Clients: Evidence from a Non-Muslim Country. Kyoto Bulletin of Islamic Area Studies, 7, 67-97.

Obaidullah, M. (2008). Role of Microfinance in Poverty Alleviation. Jeddah: IRTI, Islamic Development Bank.

Oke, J. T. O., Adeyemo, R., \& Agbonlahor, M. U. (2007). An Empirical Analysis of Microcredit Repayment in Southwestern Nigeria. Humanity \& Social Sciences Journal, 2(1), 63-74. https://doi.org/10.1300/10911350802081592

Onyina, P. A., \& Turnell, S. (2013). The Impacts of a Microfinance Lending Scheme on Clients in Ghana, Accounting \& Taxation. The Institute for Business and Finance Research, 5(2), 79-88.

Osmani, S. R. (2016). Models of Microcredit Delivery and Social Norm. Working paper no. 50. Institute for Inclusive Finance and Development (InM).

Rahman, A. R. A. (2010). Islamic microfinance: An ethical alternative to poverty alleviation. Humanomics, 26(4), 284-295. https://doi.org/10.1108/08288661011090884

Rahman, M. M., \& Ahmed, F. (2010). Impact of Microfinance of IBBL on the rural poor's Livelihood in Bangladesh: an empirical study. International Journal of Islamic and Middle Eastern finance and Economics. 3(2), 168-190. https://doi.org/10.1108/17538391011054390

Rahman, S., Rafiq, R. B., \& Momen, M. A. (2009). Impact of microcredit programs on higher income borrowers: Evidence from Bangladesh. International Business \& Economics Research Journal, 8(2), 119-124.

Raihan, S., Osmani, S. R., \& Khalily, M. A. B. (2017). The macro impact of microfinance in Bangladesh: A CGE analysis. Economic Modelling, 62, 1-15. https://doi.org/10.1016/j.econmod.2017.01.002

Roslan, A. H., \& Abd Karim, M. Z. (2009). Determinants of microcredit repayment in Malaysia: The case of Agrobank. Humanity \& Social Sciences Journal, 4(1), 45-52.

Samer, S. Majid,I. Rizal,S. Muhamad,M, R. Halim,S. \& Rashid, N. (2015). The Impact of Microfinance on Poverty Reduction: Empirical Evidence from Malaysian Perspective. Social and Behavioral Sciences, 195, 721-728. https://doi.org/10.1016/j.sbspro.2015.06.343

Shirazi, N. S. (2012). Targeting and Socio-Economic Impact of Microfinance: A Case Study of Pakistan. Islamic Economic Studies, 20(2), 1-28.

Tabachnick, G. G., \& Fidell, L. S. (2007). Experimental Design Using Anova. Belmont, CA: Duxbury Tabac.

\section{Copyrights}

Copyright for this article is retained by the author(s), with first publication rights granted to the journal.

This is an open-access article distributed under the terms and conditions of the Creative Commons Attribution license (http://creativecommons.org/licenses/by/4.0/). 